\title{
National criminal jurisdiction over transnational financial crimes
}

\author{
Dr Chat Le Nguyen \\ Lecturer, School of Law, The University of the South Pacific
}

\begin{abstract}
Purpose - The article examines the international standards for establishing national jurisdiction over the transnational crimes of money laundering and bribery and identifies challenges to the adoption of those standards by different States in practice.

Design/methodology/approach - This article, first, defines transnational money laundering and transnational bribery; then, examines the legal bases and principles on which a State can claim criminal jurisdiction over these offences. This article also discusses the application of jurisdictional conditions in a transnational context, and how to deal with the particular problems arising from national claim of jurisdiction over these offences, e.g., jurisdictional concurrence.

Findings - This paper argues that when the jurisdictional concurrence occurs, the involved States should consult one another with taking into account of a number of relevant factors and take the "centre of gravity" approach to deciding which state or forum eventually prosecute. States less able to establish jurisdiction over the offences are often those which have a weak legal basis and/or insufficient resources.
\end{abstract}

Originality/value - This article would be the good guidance on how a State could claim jurisdiction over the offences of transnational money laundering and transnational bribery.

Key words - Money Laundering, Bribery, Criminal Jurisdiction, Jurisdictional Concurrence

Paper type - General review

\section{Introduction}

Economic globalization and advanced technologies have facilitated the commission of financial crimes, such as money laundering, corruption and financial frauds, beyond national border. A financial crime now may occur in more than one national territory. The emergence of transnational financial crimes has necessitated States to establish adequate extraterritorial jurisdiction in order to eliminate "havens" for the offenders.

National criminal jurisdiction includes: firstly, prescriptive (or legislative) jurisdiction, which denotes the authority of a State to criminalize a given form of conduct; secondly, executive jurisdiction (or enforcement jurisdiction), which indicates the power of national law enforcement agencies to investigate, arrest, detain, prosecute and confiscate the criminal proceeds; and thirdly, adjudicative jurisdiction over a criminal case. Driven by the principle of sovereign equality and territorial integrity of States, in general criminal jurisdiction is 
facultative rather than mandatory. The exercise of criminal jurisdiction is ultimately a matter for individual States.

Nevertheless, the gravity of transnational crime has forced States to join different international conventions in order to set up regulations of establishing national jurisdiction over the certain criminal offences. These regulations are stated in article 4 of United Nations Convention against Illicit Traffic in Narcotic Drugs and Psychotropic Substances (1988 Vienna Convention) (UN, 1988), article 15 of United Nations Convention against Transnational Organized Crime (Palermo Convention) (UN, 2000), and article 42 of United Nations Convention against Corruption (UNCAC) (UN, 2003). These frameworks provide for both binding and permissive jurisdiction. Accordingly, the State Parties "shall" assert its jurisdiction over the given offences based upon the principle of strict territoriality or "quasiterritoriality"[1], and "may" extend its jurisdiction over such offences in several ways beyond their territory, known as extraterritorial jurisdiction. Although the assertion of extraterritorial jurisdiction over the given offences is necessary to prevent the offenders from utilizing national borders for the avoidance of prosecution, it is optional.

The general permissive bases for establishing national criminal jurisdiction include: territoriality and its variations, nationality (or active personality), passive personality, protective principle, and universality. In addition, the exercise of jurisdiction over transnational crime should have to satisfy certain further conditions and principles, of which the double/dual criminality and the principle of non bis in idem (or prohibition of double jeopardy in common law States) are the most important. However, the application of these principles and conditions varies upon different type of transnational crime with its own characteristics and constituent elements, and sometimes is controversial.

The term "transnational crime" was first used by the United Nations (UN) Crime Prevention and Criminal Justice Branch at the Fifth UN Congress on the Prevention of Crime and Treatment of Offenders (1975) "in order to identify certain criminal phenomena transcending international borders, transgressing the laws of several states or having an impact on any countries" (Mueller, 2001, p. 272). In the Fourth UN Survey of Crime Trends and Operations of Criminal Justice System (1995), transnational crimes were described as "offences whose inception, perpetration and/or direct or indirect effect involved more than one country" [2]. Following this approach, article 3(2) of the Palermo Convention provides that an offence is "transnational" in nature if it satisfies one of the following features: a) it is committed in more than one State; b) it is committed in one state but a substantial part of its preparation, planning, direction or control takes place in another State; c) it is committed in one state but involves an 
organized criminal group that engages in criminal activities in more than one state; or d) it is committed in one state but has substantial effects in another state. It should be noted that the adjective "transnational" usually implies cross-frontier activities, however entirely intranational offence may be justified as "transnational" offence, for example if it belongs to category (d) of the Palermo Convention provision.

This article examines and discusses how a State establishes criminal jurisdiction over transnational financial crimes, with the focus on transnational money laundering and transnational bribery. This paper is structured in three parts: i) the general concept of transnational money laundering and transnational bribery; ii) the bases and principles on which a State can claim criminal jurisdiction over these offences; ii) the application of jurisdictional conditions in a transnational context; and iii) how to deal with the particular problems arising from national claim of jurisdiction over these offences, e.g., jurisdictional concurrent.

\section{Transnational money laundering}

Despite different definitions, money laundering is generally understood as the process of converting the proceeds derived from underlying criminal offences, called predicate offences, to apparently legitimate property [3].

The conduct elements of money laundering are spelled out in article 3(1)(b) of the 1988 Vienna Convention), article 6(1) of the Palermo Convention, and article 23(1) of UNCAC as follows:

(a) (i) [T]he conversion or transfer of property, knowing that such property is the proceeds of crime, for the purpose of concealing or disguising the illicit origin of the property or of helping any person who is involved in the commission of the predicate offence to evade the legal consequences of his or her action;

(ii) The concealment or disguise of the true nature, source, location, disposition movement or ownership of or rights with respect to property, knowing that such property is the proceeds of crime;

(b) Subject to the basic concept of its legal system:

(i) The acquisition, possession or use of property, knowing, at the time of receipt, that such property is the proceeds of crime.

(ii) Participation in, association with or conspiracy to commit, attempts to commit and aiding, abetting, facilitating and counselling the commission of any of the offences established in accordance with this article.

Article 3(3) of the 1988 Vienna Convention and article 6(2)(f) of the Palermo Convention provides the mens rea of money laundering with two central elements: the intent to commit the 
conduct elements of the offence, and knowing that the property is derived from the predicate offences or from an act of participating in such activities (known as the "knowledge" element).

It should be noticed that there is no money laundering offence without a predicate offence. Article 6(2)(c) of UNCAC stipulate that "predicate offences shall include offences committed both within and outside the jurisdiction of the State Party in question".

States categorize predicate offences for money laundering differently. For example, New Zealand categorizes all criminal offences as predicate offences. Section 243(1) of Crimes Act 1961 , states that a predicate offence is "an offence (or any offence described as a crime) that is punishable under New Zealand law, including any act, wherever committed, that would be an offence in New Zealand if committed in New Zealand". In Australia, predicate offences are all indictable offences [4]. Under Australian law, an indictable offence is one with a penalty of a minimum of 12 months imprisonment. The United States (US) refers to a specific list of predicate offences [5]. According to section 261(1) of the "Strafgesetzbuch" [Criminal Code] (Germany), the predicate offences for money laundering in Germany cover all serious offenses plus a number of specifically listed misdemeanors.

For the discussion of jurisdiction in this paper, a money laundering offence is considered to be "transnational" if: i) it has one of the alternative features of transnational offences provided for in article 3(2) of the Palermo Convention; or ii) when the predicate offence was committed abroad. It is noticeable that scenario (i) and (ii) may overlap. Under scenario (ii), in the circumstance when the predicate oofence occurred and generated the proceeds abroad, the money laundering activity is actually trans-boundary in nature, because the proceeds has been transferred out of the original country. In other circumstances, the nature of the money laundering activity itself may be not transnational, but the investigation and prosecution for the money laundering activity may require interstate cooperation. For example, the cross-border predicate oofence was committed in State A and involved State B, the proceeds was produced and purely laundered in State B. Then if State B wishes to establish its jurisdiction over the money laundering activity, it usually must ensure that the predicate activity constitutes a crime under its law. For doing so, State B needs the cooperation from State A, such as exchanging information or evidence about the predicate activity.

\section{Transnational bribery}

Transnational bribery occurs when a person (natural or legal) from one country (the home country) bribes a public official of another country (the host country) (Nichols, 1999, pp. 25859). Transnational bribery has been recognized as an increasing problem in international 
business transactions which harms both home countries (normally developed countries) and host countries (usually developing countries) (Obidairo, 2013, pp. 35-36). As a result, various bilateral and multilateral legal instruments, which oblige their State Parties to criminalize the activity of bribing foreign public officials, have been formulated to regulate and suppress transnational bribery. Most States have criminalized bribery and many have made the bribery of foreign public officials a criminal offence. Article 1(1) of the Convention on Combating Bribery of Foreign Public Officials in International Business Transactions (OECD Convention) and article 16(1) of UNCAC state as follows:

Each State Party shall adopt such legislative and other measures as may be necessary to establish as a criminal offence, when committed intentionally, the promise, offering or giving to a foreign public official or an official of a public international organization, directly or indirectly, of an undue advantage, for the official himself or herself or another person or entity, in order that the official act or refrain from acting in the exercise of his or her official duties, in order to obtain or retain business or other undue advantage in relation to the conduct of international business.

Article 2(b) of UNCAC defines a foreign public official as "any person holding a legislative, executive, administrative or judicial office of a foreign country, whether appointed or elected; and any person exercising a public function for a foreign country, including for a public agency or public enterprise".

\section{Establishing criminal jurisdiction over transnational financial crimes}

As noted earlier, State Parties to the 1988 Vienna Convention, the Palermo Convention, and UNCAC (hereafter called "suppression conventions") "shall" and "may" establish their jurisdiction over certain offences, based on basic principles of: territoriality and its variations, nationality, passive personality, protective principle, and universality. Nevertheless, not all these principles are applicable to the establishment of jurisdiction over transnational money laundering or bribery.

The passive personality principle, which grants jurisdiction to the State of which the victim is a national, does not work in case of bribery and money laundering offences since victims of these offences can hardly be individualized.

The protective principle, which gives a State criminal jurisdiction over exterritorial conduct of aliens that violates the vital protected national interests of that State, seems not to be applicable to bribery and money laundering offences. Because it is difficult to prove whether 
bribery or money laundering committed abroad by aliens injures vital protected national interests.

When it comes to the absolute universality principle, this principle grants every State jurisdiction over an offender founded in the territory of that State, provided that the offence committed by the offender must belong to the category of jus cogens international crimes (e.g., genocide, crimes against humanity, and war crimes) (Bassiouni, 2002, p. 82), regardless of where the offence is committed. Neither bribery nor money laundering offences are among these offences, thus this principle is of no use in respect of these offences.

The discussion of this paper now focuses mainly on the jurisdictional principles provided for in the suppression conventions, as these conventions all contain obligations to the jurisdictional aspects of transnational bribery and money laundering, and most States are now Parties to them.

\subsection{Territoriality and its variations}

Criminal jurisdiction is primarily territorial or, in other words, based upon the principle of territoriality. This principle is accepted as the most substantial basis for a State to claim criminal jurisdiction over an offence committed within its own territory. The suppression conventions all require each State Party to establish jurisdiction over bribery and money laundering offences, upon the strict territorial or "quasi-territorial" basis. Article 15(1) of the Palermo Convention states:

Each State Party shall adopt such measures as may be necessary to establish its jurisdiction over the offences established in accordance with articles 5, 6, 8 and 23 of this Convention when:

(a) The offence is committed in the territory of that State Party; or

(b) The offence is committed on board a vessel that is flying the flag of that State Party or an aircraft that is registered under the laws of that State Party at the time that the offence is committed.

Nonetheless, a transnational crime often occurs in more than one State, therefore, the concerned questions are which State's territory the crime is considered to have been committed, and thus, which State may exercise territorial jurisdiction over the crime. In practice, a crime is usually considered to be committed in the territory of a State when only one or some constituent elements of the crime actually occurred within the territory of that State. These elements can be the acts or results of the crime. The territorial jurisdiction has been variably expanded in its application to the establishment of jurisdiction over transnational crime. The 
State Parties have employed various approaches in establishing their broad territorial jurisdiction (Blakesley and Lagodny, 1991, p. 73).

Given the concepts of transnational bribery and money laundering offences, these offences can be conceived of as "conduct offences" and not as "result offences". The harmful effect of bribery and money laundering offences is usually not a constituent element of the offences. Thus, every State, on whose territory a conduct element of bribery or money laundering offences occurred, can claim jurisdiction over the entire offence.

Under 18 USC $\S$ 1956(a)(2), the US exercises territorial jurisdiction over anyone who "transports, transmits, or transfers, or attempts to transport, transmit, or transfer a monetary instrument or funds from a place in the US to or through a place outside the US or to a place in the US from or through a place outside the US”. In addition, under 18 USC § 1956(f), there is territorial jurisdiction over the money laundering offence committed by a non-US citizen which occurs in part in the US and involves funds or monetary instruments of a value exceeding US $\$ 10,000$, even if the defendant has not been physically present in the US during the commission of the offence. Accordingly, a foreign citizen, who makes a wire (or by other means) transfer of funds from or to the US while being abroad, is deemed to have acted "in part" in the US. In United States v. Stein [6], the defendant, who initiated a transfer of funds from a place within the US to a place abroad without the physical presence in US, is subject to territorial jurisdiction.

Generally, under the US Foreign Corrupt Practices Act of 1977 (FCPA), the US asserts territorial jurisdiction over conduct both inside and outside its territoriality. Foreign persons may be prosecuted for using the US mails or any means or instrumentality of interstate commerce or to do any other act in furtherance of bribery of a foreign official [7]. 15 USC $\S \S$ 78dd-2(h)(5) defines "interstate commerce" as "trade, commerce, transportation, or communication among the several States, or between any foreign country and any State or between any State and any place or ship outside thereof....".

Canada can claim territorial jurisdiction over a transnational financial crime committed by a foreign citizen and occurred entirely outside Canada, provided that there is a "real and substantial connection" between the crime and Canada. In R. v. Karigar [8], the defendant was convicted of agreeing with others to offer bribes to foreign public officials under the old version of the Corruption of Foreign Public Official Act (Canada). Although the offence occurred in other States (the US and India) and no constituent element existed in Canada, the court still established territorial jurisdiction over the case because it proved that there was a "real and substantial connection" between the offence and Canada. In this case, the defendant was a 
Canadian resident for many years and was employed by or/and acted as an agent of a Canadian Company. This application is consistent with Commentaries on the OECD Convention, which states that "the territorial basis for jurisdiction should be interpreted broadly so that an extensive physical connection to the bribery act is not required" (OECD, 2011).

The territorial theory is also applied to the offences enumerated in article 15(2)(ii) of the Palermo Convention which are actually a type of conduct falling under money laundering offences - "participation in, association with, conspiracy,...". Accordingly, a State Party may establish jurisdiction over any of these offences committed outside its territory with a view to the commission of money laundering offences within its territory.

\subsection{Nationality principle}

Under the nationality principle, a State is entitled to assert criminal jurisdiction over an accused who is its nationals, even when he/she is found outside their territory, and even when the perpetrator is no longer a national or has only become a national after committing crime (Ryngaert, 2008, p. 88). From the perspective of international law, this principle is underpinned by the rationale that a State retains its sovereignty over its nationals, even though they are traveling or residing abroad, and retains its respect internationally by punishing its own wrongdoers (Blakesley and Lagodny, 1991, p. 25). A State can, based on allegiance, assert criminal jurisdiction over the acts of one of its nationals deemed criminal under that State's laws (Bassiouni, 1986, p. 23).

In accordance with jurisdictional provisions in the suppression conventions, such as article 42(2)(b) of UNCAC, State Parties may establish extraterritorial jurisdiction over bribery and money laundering offences committed abroad by their own nationals. Under these provisions, unlike the strict territoriality principle, the nationality principle is optional rather than mandatory. An extended application of the nationality principle is the permissive establishment of jurisdiction over habitual residents. Article 15(2)(b) of the Palermo Convention and article 42(2)(b) of UNCAC provides that a State Party may establish jurisdiction when "the offence is committed by a national of that State Party or a stateless person who has his or her habitual residence in its territory".

Although the nationality principle is universally recognized, its application varies significantly from State to State. Continental law States apply the national principle in a substantially expansive manner. Section 7(2)1 of the German Criminal Code states that "German criminal law shall apply to other offences committed abroad if the act is a criminal offence at the locality of its commission or if that locality is not subject to any criminal law 
jurisdiction, and if the offender was German at the time of the offence or became German after the commission".

On the other hand, common law States have traditionally been reluctant to apply this principle. States limit the application of nationality principle to given offences because of numerous reasons. One of the reasons is that the territorial and nationality principle and the incidence of dual nationality create parallel jurisdictions and possible double jeopardy (Brownlie, 2008, p. 304). Under section 7A of Crimes Act 1961, New Zealand applies the principle to certain offences with transnational aspects, excluding money laundering. The US exercises its jurisdiction on the nationality principle over a relatively small number of offences, which impact on some important State interest, including money laundering offences [9]. Canada also applies the nationality principle to money laundering offences. In R. v. Hape [10], Canadian courts, based on the nationality principle, convicted a Canadian businessman of money laundering in associated with an investment company located in the Turks and Caicos Island. With the permission from the Turks and Caicos Islands, Canadian authorities had conducted parts of their investigation on the Islands, such as searched the accused's office and gathered the documentary evidence.

Upon on the nationality principle, 15 USC $\S \S 78 \mathrm{dd}-2(\mathrm{i})$ allows the US to exercise jurisdiction over US nationals and companies, who committed the offence of transnational bribery wholly outside the US. In Canada, under section 5(2) of the new version of the Corruption of Foreign Public Official Act (implemented on 19 June 2013), Canadian citizens, permanent residents or companies can be prosecuted for transnational bribery regardless of a crime's link to Canada.

It is worth mentioning that the application of nationality principle to a foreign corporate crime is controversial in practice. The problems relate to determining nationality and legal status of corporation (whether corporation is recognized), whether the State involved accept corporate criminality, and the condition of double criminality if required. In fact, because there is no international unification of rules for the award of nationality of a corporation, the same corporation may have different nationalities. Common law States usually adhere to the rule that corporation is granted the nationality of the State under whose law it has been incorporated. Another approach (used by France and Germany) is to determine a corporate entity's nationality based upon its principal centre of business (Stessens, 2000, pp. 233-34).

\subsection{Aut Dedere Aut Judicare Principle}


The aut dedere aut judicare (extradite or prosecute) principle refers to the alternative obligation to extradite or prosecute, which is often contained in multilateral treaties to secure the prosecution for the crime of international concern (Bassiouni and Wise, 1995, p. 3). It generally obliges a State Party, in whose territory an alleged offender is found, either to extradite the offender (if it does not prosecute) to another State Party which is prepared to try him, or to prosecute him before its own competent authorities (if it does not extradite because of certain grounds). In order to do so, this principle actually imposes two legal obligations on State Parties: i) to set up their law that if they refuse/fail to extradite, they must establish their own jurisdiction; and ii) to exercise that jurisdiction in a particular case if they refuse/fail to extradite.

Included in the suppression conventions, aut dedere aut judicare can operate in a case of exercising executive jurisdiction over transnational money laundering and bribery. Assuming that an alleged offender, who is a national living in State B, committed a money laundering offence involving State A. State A has established its jurisdiction over that money laundering offence on the basis, e.g., of the principle of territoriality. State B, aware of State A's jurisdiction, has found the alleged offender in its territory. State A makes an extradition request to State B. If State B refuses to extradite, e.g., on the ground that the alleged offender is its national, State B must "submit the case to its competent authorities for the purpose of prosecution", given that State B has law which enables it to exercise jurisdiction in such a situation.

The operation of this principle is usually conditional. Usually the requested State is bound to initiate the prosecution over the offences provided for in the suppression conventions (including money laundering and corruption) if the extradition is refused only on the certain grounds. Those grounds are listed in article 4(2)(a) of the 1988 Vienna Convention: when the offence has been committed in its territory or on board a vessel flying its flag or an aircraft which was registered under its law at the time the offence was committed; or when the offence has been committed by one of its nationals; and in article 16(10) of the Palermo Convention (only when an alleged offender is one of its nationals). If the grounds, upon which the extradition is refused, are other than these, the requested State is under no mandatory obligation to initiate the prosecution.

According to the wording of "submit" in article 6(9) of the 1988 Vienna Convention and article 16(10) of the Palermo Convention, once the requested State establishes the jurisdiction, there is no mandatory obligation to actually prosecute. The requested State remains free to exercise its criminal jurisdiction subject to its domestic law. It is only required to "take their 
decision and conduct their proceedings in the same manner as in the case of any other offence of a grave nature under the domestic law".

\section{Jurisdictional conditions in a transnational context}

\subsection{Double/dual criminality}

The condition of dual/double criminality is traditionally bound up with the basic areas of international criminal law: extradition, the transfer of criminal proceedings and the execution of foreign sentences (Gardocki, 1993, p. 9). With the development of international cooperation in the fight against transnational crime, this condition has been perceived as one of the most crucial and universal conditions applied to jurisdiction, extradition and mutual legal assistance However, the double criminality condition is not a rule of customary international law. States are not automatically obliged to apply this condition in their mutual relations unless it is provided for in their treaties or domestic laws (Swart, 1996, p. 520). In general, this condition, in both cases of mutual legal assistance and jurisdiction, is fulfilled when the act is punishable under the criminal laws of both States.

The requirement of double criminality as a condition to jurisdiction relates to the question of whether the act is punishable under the law of the place of commission (lex loci delicti). The rationales behind this condition are derived primarily from State sovereignty, international solidarity and the legality principle (Wyngaert, 1996, pp. 140-42). When a crime is committed in State A and prosecuted in State B, the court in State B would, if applying the condition, raise a central question whether the act is punishable also under the law of State A. In specific situations, double criminality can be justified in abstracto or in concreto. Generally speaking, double criminality in abstracto is fulfilled when there is merely the existence of criminalization of the act under the criminal laws of both States concerned. In a further consideration, some commentators suggest that double criminality in abstracto should comprise three cumulative components (Feller, 1975, p. 70): i) the existence of a legal norm prohibiting the act in both States; ii) the act is punishable in both States, in respect of the law applicable at the time the act was committed as compared with the law applicable at the time of the legal proceedings; and iii) the act is punishable under the laws of both States in respect of the place where the act was committed. Double criminality in concreto goes beyond the fulfillment of double criminality in abstracto. It includes the elements of double criminality in abstracto illustrated above, and takes into account the concrete circumstances of the act from the point of view of criminality liability, such as: age and sanity of the doer, various grounds for the negation and exemption of criminal liability (Feller, 1975, p. 71). 
The concern about double criminality of the predicate crime as a requirement for jurisdiction over money laundering will arise when the jurisdiction asserted by a State over the money laundering offence requires a link to the specific predicate crime, and this predicate crime was not committed in that State. Specifically, the question is when State A asserts jurisdiction over a money laundering act that involves the proceeds from the predicate crime committed in State B, whether State A should require double criminality of the predicate crime in order to establish its jurisdiction.

One of the issues, that have to be proved when asserting jurisdiction over the money laundering act, is that the property laundered must originally be criminal proceeds. In the above hypothetical case, under the criminal law of State B, obviously, the proceeds are criminally generated from the predicate criminal activity which occurred in State B. Furthermore, when State A establishes jurisdiction over the money laundering act that it may do so, this predicate activity should also constitute a criminal offence under the law of State A. State A should require double criminality in respect of the predicate crime to secure the legality principle. Nevertheless, it is optional according to the suppression conventions. For example, article 6(c) of the Palermo Convention states that "[O]ffences committed outside the jurisdiction of the State Party shall constitute predicate offences only when the relevant conduct is a criminal offence under the domestic law of the State where it is committed and would be a criminal offence in the domestic law of the State Party implementing or applying this article had it been committed there".

In the practice of prosecution for money laundering offences, it is burdensome to prove the precise criminal origin of proceeds generated from a predicate crime in concerto. Especially, when defendants are third parties (i.e. the criminal proceeds are laundered by persons who are not involved in the commission of the predicate offence); or advanced and complicated money laundering typologies, such as the extensive use of shell companies or cyber-laundering, are used to hide the trails of criminal proceeds [11]. In many countries, e.g., Australia and New Zealand, proof of a specific predicate offence is not required [12]. Hence, most States, in the same situation as State A (where the money laundering offence occurs), only require double criminality of the predicate crime in abstracto for the prosecution of the money laundering offence under its law (Durrieu, 2013, pp. 407-08). However, Russia still adopts the in concreto approach (Reynolds, 2003, p. 20). It can be seen that, in order to succeed in a jurisdictional claim over transnational money laundering cases, States should 'relax' the requirement of double criminality of the predicate offence. 


\subsection{Non Bis In Idem in a transnational context}

The recognition of multiple principles for the exercise of jurisdiction over transnational crime may lead to the situation in which the conduct in question is subject to the concurrent criminal jurisdiction of two or more Sates. In this situation, the transnational application of the non bis in idem principle [13], a continental equivalent of the common law principle against double jeopardy (Sigler, 1963, pp. 283-99), functions as a bar to new prosecution or enforcement of penalties for the same offender (enforcement jurisdiction).

The principle of non bis in idem is traditionally applied to purely domestic justice as a fundamental procedural safeguard for defendants facing criminal proceedings. The application of non bis in idem at a national level is also provided for in article 14(7) of the International Covenant on Civil and Political Rights as follows: "[N]o one shall be liable to be tried or punished again in criminal proceedings under the jurisdiction of the same State for an offence for which he has already been finally acquitted or convicted in accordance with the law and penal procedure of that State" [14]. This principle is especially emphasized in case law in many different States. Once a case has been disposed of, it should not be reopened; and, the final outcome of a judicial proceeding should be respected and accepted by other courts (the doctrine of res judicata) (Wyngaert and Stessens, 1999, p. 781).

The transnational application of non bis in idem was initiated by member States of the European Communities in 1987 through the Convention between the Member States of the European Communities on Double Jeopardy. Article 54 of the Schengen Implementation Agreement (1990) provides that "a person who has been finally judged by a Contracting Party may not be prosecuted by another Contracting Party for the same offences provided that, where he is sentenced, the sentence has been served or is currently being served or can no longer be carried out under the sentencing laws of the Contracting Party”. Eurojust [15] also implies the non bis in idem principle in its guidance to deal with the jurisdictional concurrence in crossborder cases (Eurojust, 2016). Nevertheless, many continental law States (among many others) do not recognize the res judicata effect of foreign criminal judgments. Only some European States, which are Parties to the Schengen Implementation Agreement, recognize this effect.

The cross-border application of non bis in idem is controversial and limited. Controversy surrounding the recognition of foreign judgment on transnational crime is a primary hindrance to the application. Specifically, if authorities of one State take judicial steps against the alleged perpetrator of a transnational crime, will the outcomes of this procedure be recognized or binding on the concerned judicial bodies of the other States which also assert jurisdiction over the transnational crime? In addition, some States tend to apply the non bis in idem principle in 
abstracto, whereas others prefer the in concreto application (Conway, 2003, pp. 227-28). In practice, because there is no concrete provision of international law that makes the principle of non bis in idem mandatory at the international level [16], States are often reluctant to recognize the validity of a foreign criminal judgment on the crime that happened in their territory (Gless, 2017, pp. 228-31). The recognition is normally based on bilateral or multilateral treaties dealing with judicial cooperation in criminal matters (Vervaele, 2013, p. 229). In particular, common law States are normally unsure if States from other legal traditions adhere to the rules of evidence in a common law criminal trial. While some civil law States, such as Netherland, Spain, France, Belgium and Switzerland, recognize a res judicata effect of foreign criminal judgments; others, e.g., Germany, do not (Gless, 2017, pp. 229-31).

\section{Dealing with concurrent jurisdiction}

\subsection{International provisions}

In a case of transnational crime, the States concerned can assume their jurisdiction over the crime based upon the different aforementioned principles. Nevertheless, neither general international law nor the suppression conventions provide a hierarchical application of jurisdictional principles. Thus, States normally do not have to struggle with the question of whether their own law permits them to establish jurisdiction over the crime, but rather which of the competing States has the most appropriate jurisdiction. In practice, although it is difficult to give detailed guidelines or mechanisms for prioritizing concurrent criminal jurisdiction claims at the international level, some suggestions have been given. The suppression conventions, such as article 21 of the Palermo Convention, suggest that "States Parties shall consider the possibility of transferring to one another proceedings for the prosecution of an offence established in accordance with this Convention in cases where such transfer is considered to be in the interests of the proper administration of justice, in particular in cases where several jurisdictions are involved, with a view to concentrating the prosecution". In another approach, Eurojust suggests that a prosecution should take place in the State "where the majority of the criminality occurred or where the majority of the loss was sustained", and that a number of listed factors should be taken into account in making the final decision as to which State is the most appropriate forum for a prosecution (Eurojust, 2016, pp. 2-4). In addition, the UN's report on economic fraud also recommends elaborate criteria which should be considered to decide the most convenient forum for the prosecution for transnational frauds, when more than one State have jurisdiction and want to prosecute (UN, 2007, pp. 17-19). These criteria are: 
(a) The State which has suffered from the greatest direct and indirect harm. Harm provides incentive and justification for the prosecution. This State also usually has available evidence;

(b) The State in which most of the elements of the offence were committed;

(c) The State that has the greatest investment for investigative efforts in the case. This State usually has the commitment of resources and more evidence for prosecution;

(d) The location of witnesses and evidence. Transferring evidence may cost significantly, and may affect the legal admissibility of the evidence;

(e) The State that has the strongest case;

(f) The State with the best capacity. States with extensive experience and resources may take prosecution, if that is legally feasible, or assist another State that has a claim but less capacity;

(g) The nationality of the offender and whether he or she can be extradited;

(h) Other offences involved or which may be prosecuted;

(i) Other offenders that are involved or may be prosecuted;

(j) The respective sentencing regimes. States are normally willing to cede jurisdiction to other States with similar punishment for the crime committed.

The UN's recommendation can be used when dealing with jurisdictional concurrence over other transnational crimes, such as bribery and money laundering. The suggestion and recommendation appears to indicate a tendency towards the application of the conflict of laws approach, such as the "centre of gravity" principle (Boister, 2018, p. 171) and the forum non conveniens doctrine [17], to resolving instances of competing jurisdiction over transnational crime. The above-listed factors should be considered as criteria for determine the "centre of gravity" or the most convenient forum for prosecution of transnational bribery or money laundering offences.

In practice, whatever factors are ultimately employed to justify the States' interests in the prosecution, negotiation and cooperation between the States involved is essential for evaluating and balancing those factors, then to reach a decision where to prosecute. The requirement of consultation and coordination is also provided for in the suppression conventions, e.g., in article 15(5) of the Palermo Convention. The relevant States authorities should also consult with each other about the substance and procedure of prosecution, such as the application of any procedural defences or the allocation of cases. For example, in United States of America v. Cotroni; United States of America v. El Zein [18], the US and Canada both wants to prosecute two fugitives for offences relating to conspiracy to import and distribute heroin in the US. The 
Court acknowledged the challenges of transnational crime and adopted the list of criteria that should be taken into consideration when dealing with concurrent jurisdiction. The Court held that in practice, deciding whether to prosecute or extradite, is made after consultations on the relevant factors between the domestic relevant authorities in both states. The Crown Prosecution Service of England \& Wales (CPS) has also published guidelines on the handling of cases where the jurisdiction to prosecute is shared with prosecuting authorities overseas (CPS, 2013). Accordingly, prosecutors and investigators of the relevant jurisdictions should meet in person to consider and balance the different factors when reaching a decision where to prosecute.

The International Association of Prosecutors (IAP), in its guidelines for cases of concurrent jurisdiction, highlights the importance of comprehensive multilateral consultations and recommends venues facilitating the meetings (IAP, 2013, p. 9). Meetings should be arranged at a mutually agreed venue between nominated senior prosecutors representing each jurisdiction involved. The determination should be reached together with all relevant authorities in each jurisdiction in accordance with any relevant bilateral, regional and international legal frameworks. The international and regional organisations, to which involved States are their members, can assist with consultations (e.g., the International Criminal Police Organization (INTERPOL), Eurojust, European Judicial Network (EJN), Organization of American States (OAS), Ibero-American Association of Public Prosecutors (IberRed), Caribbean Community (CARICOM), Association of Southeast Asian Nations (ASEAN), South Asian Association for Regional Cooperation (SAARC)).

What we could see from the above guidelines is that States with insufficient legal frameworks and resources would have a weak claim in competing jurisdiction over transnational crime.

\subsection{Settlement agreements on the prosecution of corporate financial crimes}

While settlement agreements in criminal proceedings are foreign to many countries, some countries, e.g., the US and the UK, have an established tradition of using plea bargain. When it comes to settlement agreements on the prosecution of commercial organizations committed financial crimes (e.g., corruption), the US and the UK are still the forerunners. The deferred prosecution agreements (DPAs) and non-prosecution agreements (NPAs) are used by the US Department of Justice (DOJ) or the US Securities and Exchange Commission (SEC). Under these agreements, a company must comply with certain conditions, e.g., financial penalties, to be exempted from being prosecuted for certain financial offences, which include transnational 
bribery (SEC, 2016). DPAs are also used by the UK Serious Fraud Office (SFO) [19]. Accordingly, a UK deferred prosecution agreement refers to "an agreement reached between a prosecutor and an organisation, which could be prosecuted, under the supervision of a judge. The agreement allows a prosecution to be suspended for a defined period provided the organisation meets certain specified condition. DPAs can be used for fraud, bribery and other economic crime". DPAs would enable prosecutors to secure penalties for and the surrendering of the proceeds of wrongdoing, and providing benefits for victims, without the uncertainty, expense, complexity or length of a full criminal trial. They also enable companies to be held to account, but without unfairly affecting employees, customers, pensioners, suppliers and investors who were not involved in the behaviour that is being penalised (UK, 2012, p. 4). In addition, this approach could enhance prosecutors' ability to detect and pursue transnational financial crime committed by commercial organisations (UK, 2012, p. 6). Transnational nature of the crime was often the cause of long, expensive and complicated criminal proceedings, especially the potential concurrent jurisdiction.

\subsection{Hypothetical case study of transnational money laundering}

Let us assume that $\mathrm{Mr} \mathrm{X}$, who is a national of State A, has participated in the transnational money laundering offence involving conduct in State B and State C. He travels to State B to commit an act of money laundering. In State B, he deposits illegal funds in banks, and then he transfers these funds through accounts at various banks in State B. Finally, the funds are transferred and integrated in State $\mathrm{C}$, for example, by investing them in real estate. The fund transactions are mainly carried out by the internet banking. It appears that States A, B and C each have jurisdiction over the "same" conduct of "transferring illegal fund knowing that such fund is the proceeds of crime" which results in the "same" money laundering offence. States B and $\mathrm{C}$ can each establish jurisdiction to adjudicate on $\mathrm{Mr} \mathrm{X}$ for the "same" money laundering offence based upon the territoriality principle. In addition, State A may impose jurisdiction to adjudicate on $\mathrm{Mr} \mathrm{X}$ based upon the principle of nationality. In this hypothetical case, there is a potential situation of concurrent jurisdiction where more than one State claim jurisdiction over the same offender or offence. Assuming that States A, B and C each seek to prosecute Mr X for the "same" offence based upon the principle of territoriality or nationality, this situation will be discussed hereinafter.

In practice, the principle of non bis in idem should be applied to this transnational context, as a result $\mathrm{Mr} \mathrm{X}$ should not be prosecuted for the "same" offence sequentially by different States. It is also necessary to address the issue of prioritizing the claims of competing 
jurisdiction over the same money laundering offender or offence. More specifically, how and which factors should be considered to determine the most appropriate State for prosecution? In the above case, subject to the UN's suggestion (UN, 2007), custody of the offender and nationality of the offender can be factors that are in favour of awarding jurisdictional priority. Assuming that $\mathrm{Mr} \mathrm{X}$ is apprehended in State C; rationally, on the basis that there is evidence indicating he has committed money laundering in State C, State $\mathrm{C}$ should be given the first opportunity to prosecute Mr X. If other States are satisfied with the outcome of prosecution conducted by State C, they should not pursue their own prosecutions. But what if $\mathrm{Mr} \mathrm{X}$ travels to State C, commits a money laundering offence, and then returns to State A? In such a situation, both State A and State $\mathrm{C}$ have jurisdiction over the conduct in question and can prosecute Mr X. Both State A and C may want to prosecute Mr X. Under aut dedere aut judicare, State A shall either extradite Mr X to State C for prosecution or prosecute him itself. Traditionally, Mr X's nationality weighs heavily in favour of granting prosecution to State A. Another significant factor should be taken into account is the place for prosecution of the predicate offence. The State, which prosecutes both the money laundering offence and its predicate offence, may arguably have a weightier claim to go first. In the situation where a State with a weaker legal basis has invested more resources into the investigation and has greater capacity, such State may have a better claim.

In brief, the principle of territoriality is the predominant principle for the assertion of jurisdiction over transnational money laundering. This principle is given priority over other bases, such as nationality and aut dedere aut judicare principle. While the application of the territoriality principle is widely mandatory, the application of other principles is optional, limited or discretionary.

The nature of transnational money laundering offences potentially leads to problems of concurrent jurisdiction over the "same" money laundering offence. The priority of a jurisdictional claim depends on the combination of convincing grounds in particular cases. In some circumstances, a State which combines territorial jurisdiction with custody of the offenders should have the better claim. In others, the combination of nationality principle and custody of offender should have the priority. In addition, in some cases, the State, where the predicate crime was committed or prosecuted, should be favoured. However, in practice, States traditionally first proceed with consultation and negotiation in dealing with the jurisdictional concurrence, as mentioned above.

\section{Conclusion}


The emergence of transnational money laundering and bribery offences has necessitated the extension of national criminal jurisdiction beyond national boundaries over those offences. States should establish adequate criminal jurisdiction over these transnational offences to eliminate "havens" for the offenders. In order to avoid controversial unilateral assertion of their jurisdiction, States have agreed on a number of principles based on which their jurisdiction over the transnational offences is established. By adopting the suppression conventions, the State Parties are provided with both the mandatory and optional jurisdictional principles for transnational financial offences. Territoriality, nationality and aut dedere aut judicare are the possible bases for the establishment of jurisdiction over money laundering and bribery offences. Due to some weaknesses of the nationality and aut dedere aut judicare principle, such as the problems of dual nationality or nationality of corporations, the principle of territoriality enjoys the predominant role as it has done traditionally. In fact, States often apply these jurisdictional principles in combination rather alone. In addition, the assertion of territorial jurisdiction over a money laundering offence should take account of double criminality of the predicate offence and non bis in idem. When the jurisdictional concurrence occurs, the involved countries should consult one another with taking into account of a number of relevant factors and take the "centre of gravity" approach to deciding which State or forum eventually prosecute. Less-favoured States are often those which have a weak legal basis and/or insufficient resources.

\section{Notes}

1. The "quasi- territoriality" principle binds States to establish jurisdiction over specific crimes committed in their flag-vessels and registered aircrafts.

2. Results of the supplement to the Fourth United Nations Survey of Crime Trends and Operations of Criminal Justice System, on Transnational Crime 1995, UN Doc. A/CONF.169/15/Add.1.

3. See, President's Commission on Organized Crime (the US), "The Cash Connection: Organised Crime, Financial Institutions, and Money Laundering", Books for Business New York - Hong Kong, 2001, p. 7.

4. Criminal Code Act 1995 (consolidated as of 31 October 2012) (Australia), Division 400.1(1).

5. Predicate offences for money laundering cover the designated federal, state and foreign crimes. Around 250 predicate offences are listed in 18 USC $\S 1956$ (c)(7) and include all of the Racketeer Influenced and Corrupt Organization (RICO) predicate offences listed in 18 USC\$1961(1).

6. United States v. Stein (1994), No. 93-375, 1994 WL 285020.

7. See, The US Department of Justice and Securities and Exchange Commission, "A Resource Guide to the U.S. Foreign Corrupt Practices Act", available at: https://www.justice.gov/sites/default/files/criminal-fraud/legacy/2015/01/16/guide.pdf.

8. $R v$ Karigar 2013 ONSC 5199.

9. 18 USC $\S 1956(f)$ implies extraterritorial jurisdiction over the money laundering offence committed by a US citizen which involves funds or monetary instruments of values exceeding US\$10,000. 
10. $R$ v Hape [2007] 2 S.C.R.292.

11. DPP v Bholah [2011] UKPC 44.

12. See s400.13 of the Criminal Code Act 1995 (Australia) and s243(5) of the Crimes Act 1961 (New Zealand).

13. This phrase is interpreted differently into English by numerous authors. In general, this principle prevents a person from being imposed multiple trials and punishment for the same criminal offence by courts of the same State.

14. See, The International Covenant on Civil and Political Rights, 16 December 1966, 999 UNTS 171 (entered into force 23 March 1976), article 14(7).

15. Eurojust, established in 2002, aims at strengthening coordination and cooperation between national investigating and prosecuting authorities in relation to serious crimes affecting two or more the EU Member States. Eurojust consists of 27 national members who are judges, prosecutors or police officers of equivalent competence.

16. Article 15(5) of the Palermo Convention only suggests that: "If a State Party exercising its jurisdiction under paragraph 1 or 2 of this article has been notified, or has otherwise learned, that one or more other States Parties are conducting an investigation, prosecution or judicial proceeding in respect of the same conduct, the competent authorities of those States Parties shall, as appropriate, consult one another with a view to coordinating their actions".

17. The doctrine of forum non conveniens (i.e. some other forum is more "appropriate") is a familiar and developed concept in the conflict of law used to determine the appropriate forum for legal proceedings in civil cases, when concurrent jurisdiction exists. This doctrine was developed by the Scottish courts; then, adopted by the US, and recently by England (see, (Collins, 1993, pp. 398400) and Spiliada Maritime Corp. v. Cansulex Ltd. [1987] AC 460). In general, when determining whether or not to exercise forum non conveniens, courts consider several factors, including: the residence of the parties, the location of evidence and witnesses, public policy, the relative burdens on the court systems, the plaintiff's choice of forum, and how changing the forum would affect each party's case.

18. United States of America v. Cotroni; United States of America v. El Zein, [1989] 1 SCR 1469.

19. DPAs were introduced on 24 February 2014, under the provisions of Schedule 17 of the Crime and Courts Act 2013. See, SFO and CPS (2014), "Deferred Prosecution Agreements Code of Practice", available at: https://www.sfo.gov.uk/publications/guidance-policy-and-protocols/deferredprosecution-agreements/.

\section{References}

Bassiouni, M.C. (Ed.) (1986), International Criminal Law, Vol. 2, Transnational Publishers, New York. Bassiouni, M.C. (2002), "Universal Jurisdiction for International Crimes: Historical Perspectives and Contemporary Practice", Virginia Journal of International Law, Vol. 42, No. 4, pp. 81-162.

Bassiouni, M.C. and Wise, E.M. (1995), Aut Dedere Aut Judicare: The Duty to Extradite or Prosecute in International Law, Martinus Nijhoff Publishers.

Blakesley, C.L. and Lagodny, O. (1991), "Finding Harmony Amidst Disagreement Over Extradition, Jurisdiction, the Role of Human Rights, and Issues of Extraterritoriality Under International Criminal Law", Vanderbilt Journal of Transnational Law Vol. 24, No. 1, pp. 1-73.

Boister, N. (2018), An Introduction to Transnational Criminal Law, 2nd edn, Oxford University Press, Oxford.

Brownlie, I. (2008), Principles of Public International Law, 7 edn, Oxford University Press.

Collins, L. (Ed.) (1993), Dicey and Morris on the Conflict of Laws, Vol. 1, Sweet \& Maxwell Limited.

Conway, G. (2003), "Ne Bis in Idem in International Law", International Criminal Law Review, Vol. 3, No. 3, pp. 217-44.

CPS (2013), "Guidelines on the Handling of Cases Where the Jurisdiction to Prosecute is Shared with Prosecuting Authorities Overseas", available at: www.cps.gov.uk/publication/directors- 
guidance-handling-cases-where-jurisdiction-prosecute-shared-prosecuting (accessed 16 April 2019).

Durrieu, R. (2013), Rethinking Money Laundering \& Financing of Terrorism in International Law: Towards a New Global Legal Order, Martinus Nijhoff.

Eurojust (2016), "Guidelines for Deciding 'Which Jurisdiction Should Prosecute?' ", available at: http://www.eurojust.europa.eu/doclibrary/Eurojustframework/Casework/Guidelines\%20for\%20deciding\%20which\%20jurisdiction\%20should\%2 Oprosecute\%20(2016)/2016 Jurisdiction-Guidelines EN.pdf (accessed 9 August 2019).

Feller, S.Z. (1975), "Significance of the Requirement of Double Criminality in the Law of Extradition", Israel Law Review Vol. 10, pp. 51-81.

Gardocki, L. (1993), "Double Criminality in Extradition Law", Israel Law Review, No. 27, pp. 288-96.

Gless, S. (2017), "Ne bis in idem in an international and transnational criminal justice perspective paving the way for an individual right?", in Wilt, H.v.d. and Paulussen, C. (Eds.), Legal Responses to Transnational and International Crimes: Towards an Integrative Approach, Edward Elgar Publishing.

IAP (2013), "Prosecutorial Guidelines for Cases of Concurrent Jurisdiction: Making the Decision'Which Jurisdiction Should Prosecute?'”, available at: www.iap-association.org/News/IAPProsecutorial-Guidelines-for-Cases-of-Concurre (accessed 17 July 2019).

Mueller, G.O.W. (2001), "Transantional Crime: Definition and Concepts", in Williams, P. and Vlassis, D. (Eds.), Combating Transnational Crime: Concepts, Activities and Responses, Routledge, p. 272.

Nichols, P.M. (1999), "Regulating Transnational Bribery in Times of Globalization and Fragmentation", The Yale Journal of International Law, Vol. 24, pp. 257-303.

Obidairo, S. (2013), Transnational Corruption and Corporations: Regulating Bribery Through Corporate Liability, Ashgate Publishing Ltd.

OECD (2011), "Convention on Combating Bribery of Foreign Public Officials in International Business Transactions and Related Documents".

Reynolds, S.J. (2003), "The "New" Criminal Code of the Russian Federation", Statutes \& Decisions: The Laws of the USSR and Its Successor States Vol. 39, No. 4, pp. 20-39.

Ryngaert, C. (2008), Jurisdiction in International Law, Oxford University Press.

SEC (2016), "Spotlight on Enforcement Cooperation Program", available at: https://www.sec.gov/spotlight/enforcement-cooperation-initiative.shtml (accessed 16 April 2019).

Sigler, J.A. (1963), "A History of Double Jeopardy", The American Journal of Legal History, Vol. 7, No. 4, pp. 283-99.

Stessens, G. (2000), Money Laundering: A New International Law Enforcement Model, Cambridge University Press, Cambridge.

Swart, A.H.J. (1996), "Human Rights and the Abolition of Tranditional Principles", in Dugard, J. and Wyngaert, C.v.d. (Eds.), International Criminal Law and Procedure, Dartmouth.

UK (2012), "Consultation on a new enforcement tool to deal with economic crime committed by commercial organisations: Deferred prosecution agreements", available at: https://www.gov.uk/government/publications/consultation-on-a-new-enforcement-tool-todeal-with-economic-crime-committed-by-commercial-organisations (accessed 17 July 2019).

1988 United Nations Convention against Illicit Traffic in Narcotic Drugs and Psychotropic Substances 1582 UNTS 95 (entered into force 11 November 1990) [1988 Vienna Convention].

2000 United Nations Convention against Transnational Organised Crime 2225 UNTS 209 (entered into force 29 September 2003) [Palermo Convention].

2003 United Nations Convention against Corruption 2349 UNTS 41 (entered into force 14 December 2005) [UNCAC].

UN (2007), Results of the Second Meeting of the Intergovernmental Expert Group to Prepare a Study on Fraud and the Criminal Misuse and Falsification of Identity 
Vervaele, J.A.E. (2013), “Ne Bis in Idem: Towards a Constitutional Principle in the EU?", Utrecht Law Review Vol. 9, No. 4, pp. 211-29.

Wyngaert, C. (1996), "Double Criminality as a Requirement to Jurisdiction", in Dugard, J. and Wyngaert, C.v.d. (Eds.), International Criminal Law and Procedure, Dartmouth Publishing Co Limited, p. 530.

Wyngaert, C.V.D. and Stessens, G. (1999), "The International Non Bis In Idem Principle: Resolving Some of the Unanswered Questions", International and Comparative Law Quarterly, Vol. 48, No. 4, pp. 779-805. 